\title{
Component, LOINC Axis 1
}

National Cancer Institute

\section{Source}

National Cancer Institute. Component, LOINC Axis 1. NCI Thesaurus. Code C40565.

The name of the thing (chemical, protein, gene, cell, organ, antigen, event, action) that is being observed, assessed, detected, measured, counted, or evaluated. 